\title{
Assessing the Optimism of Payday Loan Borrowers
}

\author{
Ronald Mann*
}

\begin{abstract}
This Article compares the results from a survey administered to payday loan borrowers at the time of their loans to subsequent borrowing and repayment behavior. It thus presents the first direct evidence of the accuracy of payday loan borrowers' understanding of how the product will be used. The data show, among other things, that about 60 percent of borrowers accurately predict how long it will take them finally to repay their payday loans. The evidence directly contradicts the oft-stated view that substantially all extended use of payday loans is the product of lender misrepresentation or borrower self-deception about how the product will be used. It thus has direct implications for the proper scope of effective regulation of the product, a topic of active concern for state and federal regulators.
\end{abstract}

\section{IN TRODUCTION}

Payday lending is at the heart of debates about "alternative" financial products. Since its rise in the early 1990s, the product has gained widespread traction with consumers. In the typical transaction, an individual borrows $\$ 200-\$ 500$ and commits to repay the borrowed funds, together with a one-time fee of 12-18 percent of the loan's principal, out of the individual's next paycheck. ${ }^{1}$ Payday loans are

* Ronald Mann, Columbia Law School.

1 Ronald J. Mann and Jim Hawkins, Just Until Payday, 54 UCLA L Rev 855 (2006). The relatively high nominal interest rate reflects the cost structure of the industry. (C) 2014 by the University of Chicago. All rights reserved. 978-0-226-05246-5/2013/0021-0005 \$10.00. 
now available at about 20,000 storefront locations throughout the Nation, where more than ten million Americans borrowed money in $2010 .{ }^{2}$ To put their success in context, there are more payday lender locations in this country than there are Starbucks and McDonald's locations combined. ${ }^{3}$

Concerns about payday lending come from its role in the development of "fringe" lending, which has played a major part in the oftchronicled rise of modern America's culture of indebtedness. ${ }^{4}$ With a vehemence surprising for a product so successful with consumers, consumer advocates are almost uniformly critical of the product. ${ }^{5}$ Two attributes in particular attract the most attention. The first is the relatively high interest rates characteristic of the product, which typically are in the range of 400 percent la fixed fee of about 15 percent for a loan of two weeks or less). ${ }^{6}$ Concerns about those rates led, for example, to 2007 legislation prohibiting loans to military

On the one hand, operating costs do not decline proportionately with the size of the loan; thus, the administrative costs for small loans are quite high when measured on a percentage basis. At the same time, because the loans are effectively unsecured and typically made with relatively little inquiry into creditworthiness, losses are not insubstantial. Edward C. Lawrence and Gregory Elliehausen, A Comparative Analysis of Payday Loan Customers, 26 Contemp Econ Pol 299 (2008). For a detailed numerical analysis of the operating expenses and losses of payday lenders and how those compare to fee revenues, see Gregory Elliehausen, An Analysis of Consumers' Use of Payday Loans (George Washington University, Financial Services Research Program Monograph No 41, Jan 2009|, available at http://www.approvedcashadvance .com/docs/GWUAnalysis_01-2009.pdf.

${ }^{2}$ The Pew Project, Payday Lending in America: Who Borrows, Where They Borrow, and Why (Pew Safe Small-Dollar Loans Research Project Report, July 2012), available at http://www.pewstates.org/uploadedFiles/PCS_Assets/2012/Pew_Payday _Lending_Report.pdf.

${ }^{3}$ Donald P. Morgan, Michael R. Strain, and Ihab Seblani, How Payday Credit Access Affects Overdrafts and Other Outcomes, 44 J Money Credit \& Bank 519 (2012).

${ }^{4}$ John P. Caskey, Fringe Banking: Check-Cashing Outlets, Pawnshops and the Poor (Sage 1996); Donncha Marron, Consumer Credit in the United States: A Sociological Perspective from the 19th Century to the Present (Palgrave Macmillan 2009); Robert Mayer, Quick Cash: The Story of the Loan Shark (Northern Illinois 2010); David Graeber, Debt: The First 5,000 Years (Melville House 2011); Louis Hyman, Borrow: The American Way of Debt (Random 2012).

${ }^{5}$ Creola Johnson, Congress Protected the Troops: Can the New CFPB Protect Civilians from Payday Lending, 69 Wash \& Lee L Rev 649 (2012); Nathalie Martin and Joshua Schwartz, The Alliance Between Payday Lenders and Tribes: Are Both Tribal Sovereignty and Consumer Protection at Risk, 69 Wash \& Lee L Rev 751 (2012); Christopher Peterson, Taming the Sharks (Akron 2004).

${ }^{6}$ Mann and Hawkins, 54 UCLA L Rev at 855 (cited in note 1). 
personnel and their families at interest rates above 36 percent $^{7}{ }^{7}$ this essentially terminated payday lending to military families. ${ }^{8}$

The second concern relates to persistent use of the product. It is well known that many borrowers use the product frequently; in the common phrasing they are said to "roll over" the loans from pay period to pay period because they lack the funds to pay them off as they come due. This leads consumer advocates to fear that borrowers frequently become "mired" in debt that they could have avoided had they never used the product. ${ }^{9}$ The specific concern is that excessive optimism causes users to believe they will pay off their loans rapidly, when in fact they usually will not. Indeed, Bar-Gill and Warren go so far as to assert that no rational consumer expecting to roll over the loan would agree to the terms of a payday loan. ${ }^{10}$

These concerns are at the forefront of current regulatory initiatives at the state and federal level. At the state level, many states have adopted specific limitations on rollovers. ${ }^{11}$ Still others have adopted even stricter regimes that effectively ban payday lending at retail locations. ${ }^{12}$ But the most notable activity has come at the federal level, with the recent formation of the federal Consumer Financial Protection Bureau (CFPB). Two regulatory innovations are salient. First, the agency has not only the authority long held by the Federal Trade Commission to respond to unfair and deceptive practices, but also a new, broader power over "abusive" practices by financial firms. ${ }^{13}$ In addition to having broader substantive powers, the CFPB also has sweeping regulatory and supervisory jurisdiction

7 The Talent-Nelson Amendment, Section 670 of the John Warner National Defense Authorization Act for Fiscal Year 2007, Pub L No 109-364, 120 Stat 2083, was codified at 49 USC $\S 987$.

${ }^{8}$ Johnson, 69 Wash \& Lee L Rev at 649 (cited in note 5); Patrick Aul, Federal Usury Law for Service Members: The Talent-Nelson Amendment, 12 NC Bank Inst 163 (2008).

9 Mayer, Quick Cash (cited in note 4); Peterson, Taming the Sharks (cited in note 5); Alan M. White, Behavior and Contract, 27 L \& Ineq J 135 (2009).

${ }^{10}$ Oren Bar-Gill and Elizabeth Warren, Making Credit Safer, 157 U Pa L Rev 1 44-46 (2008). Alan White's analysis is similar. Alan M. White, Behavior and Contract, 27 L \& Ineq J 135, 159-63 (2009).

${ }^{11}$ Mann and Hawkins, 54 UCLA L Rev at 897-98 (cited in note 1).

12 National Conference of State Legislatures, Payday Lending Statutes (2013), available at http://www.ncsl.org/research/financial-services-and-commerce/payday -lending-state-statutes.aspx; Pew Project, Payday Lending in America (cited in note 2); Morgan, Strain, and Seblani, 44 J Money Credit \& Bank (cited in note 3); Sealy Hutchings and Matthew J. Nance, Credit Access Businesses: The Regulation of Payday and Title Loans in Texas, 66 Consumer Fin L Q Rep 76 (2012) (discussing recent legislative initiatives in Texas).

${ }^{13} 12$ USC $\S 5531$. 
over bank and nonbank financial service providers that previously did not exist at the federal or state level. ${ }^{14}$ Because federal regulators previously had no direct supervision over the lending practices of nonbanks like the major payday lenders, the new authority of the $\mathrm{CFPB}$ raises the possibility of major new regulatory initiatives in this area. ${ }^{15}$

Recent CFPB enforcement actions against major credit card issuers $^{16}$ suggest it will pursue its mandate vigorously, which makes an accurate perspective on the payday loan a valuable commodity. Because the CFPB has no authority to regulate interest rates ${ }^{17}$ concerns about repetitive use and rollovers are likely to be at the heart of any such regulatory initiative. For example, the director of the agency recently suggested the propriety of CFPB action against products for which "a substantial percentage of users rol[1] over their debts on a recurring basis" because those products amount to "debt traps." 18 Moreover, the CFPB's recently published white paper on payday loans directly decries the repetitive use of the product and avows an intention to consider mandating cooling-off periods as a matter of federal law. ${ }^{19}$ Press reports suggest that similar action by the Comptroller of the Currency and Federal Deposit Insurance Corporation against large banks is also in the works. ${ }^{20}$

In the spirit of the call by Sunstein for empirical validation of regulatory strategies, this study responds with a direct test of the accuracy of consumer understanding about repetitive use of the product. ${ }^{21}$ Comparing the results from a survey administered to payday loan borrowers at the time of their loans to subsequent borrowing and repayment behavior, this essay presents the first direct evidence of the accuracy of payday loan borrowers' understanding of

${ }^{14}$ The CFPB was created by Title X of Dodd-Frank, the Dodd-Frank Wall Street Reform and Consumer Protection Act, Pub L No 111-203, 124 Stat 1376, §§ 1001$1100 \mathrm{H}$. The regulatory authority directed specifically at nonbank financial service providers appears in Section 1024 of Dodd-Frank, codified at 12 USC § 5514.

${ }^{15}$ Johnson, 69 Wash \& Lee L Rev at 649 (cited in note 5).

${ }^{16}$ See In re Capital One Bank, (USA) NA, No 2012-CFPB-0001 (July 18, 2012) (consent order); In re American Express Centurion Bank, No FDIC 12315b etc (Sept 21, 2012) (consent order); In re Discover Bank Greenwood Delaware, No FDIC-11-548b etc (Sept 24, 2012) (consent order).

${ }^{17} 12$ USC $\S 5517$ (o).

${ }^{18}$ Richard Cordray, Prepared Remarks by Richard Cordray, Director of the Consumer Financial Protection Bureau (2013).

${ }^{19} \mathrm{Id}$.

${ }^{20}$ Jessica Silver-Greenberg, Major Banks Aid in Payday Loans Banned by States, NY Times (Feb 23, 2013).

${ }^{21}$ Cass R. Sunstein, Empirically Informed Regulation, 78 U Chi L Rev 1349 (2011). 
the product. In general, the evidence suggests two things. First, most borrowers do not expect that they will be free of debt at the end of the first loan term; on the contrary, more than half of borrowers expect that they will need to continue to borrow for additional pay cycles. Borrower estimates of an ultimate repayment date are realistic; the mean predicted period of borrowing after the initial loan matures is thirty-six days. Among other things, that finding directly rebuts the idea that borrowers never understand that they are likely to roll their loans over.

More important for present purposes, most (though surely not all) borrowers have a good understanding of their own use of the product. Specifically, most borrowers finally repay their loans and are free of debt within two weeks of the date they predicted on the date of the loan. The evidence that such a large share of borrowers accurately understand how the product will be used contradicts the accepted premise that substantially all extended use of payday loans is the product of lender misrepresentation or borrower self-deception about how the product will be used. More broadly, that evidence renders irrelevant the oft-stated premise of behavioral policy-making, the so-called golden rule of policy-making under which regulatory intervention is appropriate only if it can correct a choice that is an error for substantially all of those who make it. ${ }^{22}$

Section II of the Article situates the survey against prior writing about payday loans. Section III describes the survey and resulting dataset. Section IV describes the results. Section V elucidates the implications of the empirical results for the theoretical and policy debates about payday lending regulation. Section VI briefly concludes and suggests directions for extension.

\section{I. L I T ER A T UR E R E V IE W}

The focus of this essay is on the particular concern that payday loan borrowers do not understand the product, and specifically that a bias toward optimism causes them systematically to overestimate the likelihood that they will be able to free themselves from debt promptly. The idea of an optimism bias is often attributed to the well-known study by Weinstein of the life expectations of students. ${ }^{23}$ The basic concept is that individuals systematically assess their own future opportunities and behavior with undue and excessive

${ }^{22}$ Richard H. Thaler and Cass R. Sunstein, Nudge: Improving Decisions about Health, Wealth, and Happiness (Yale 2008).

${ }^{23}$ Neil D. Weinstein, Unrealistic Optimism about Future Life Events, 39 J Personality \& Soc Psych, 806 (1980). 
optimism. Buttressed by numerous empirical studies ${ }^{24}$ the idea has been widely accepted as a basic tenet of the behavioral economics literature..$^{25}$

Among legal academics, concerns about the optimism bias as a cause of excessive use of payday loans have been pervasive. The claim has been pressed in passing by several scholars, ${ }^{26}$ but by far the most prominent and detailed support for that perspective comes from Oren Bar-Gill and Elizabeth Warren. Payday loans are one of the central examples in their work "Making Credit Safer." 27 Their strategy with respect to payday loans is to suggest that borrowers who roll their loans over have underestimated the risk of nonpayment, reflecting their premise that no rational consumer would borrow from a payday lender with an expectation to roll over the loan. Thus, they argue, only the "customer who misestimates her ability to repay the loan in fourteen days will likely roll the loan over." 28 That perspective is particularly important because of their role in the creation and design of the $\mathrm{CFPB},{ }^{29}$ and because of Warren's place now in the United States Senate (on the Senate Banking Committee), where she can be expected to play a key role in financial regulation.

A similar perspective pervades the more recent work of the Pew Charitable Trusts' Safe Small-Dollar Loans Research Project. A 2012 study based on a nationally representative survey of payday lending

\footnotetext{
${ }^{24}$ Ernest J. Doleys and Guy A. Renzaglia, Accuracy of Student Prediction of College Grades, 41 Personnel \& Guidance J 528 (1963); Lynn A. Baker and Robert E. Emery, When Every Relationship Is Above Average: Perceptions and Expectations of Divorce at the Time of Marriage, 17 L \& Human Beh 439 (1993); Phanikiran Radhakrishnan, Holly Arrow, and Janet A. Sniezek, Hoping, Performing, Learning, and Predicting: Changes in the Accuracy of Self-Evaluations of Performance, 9 Hum Performance 23 (1996); Terence R. Mitchell, et al, Temporal Adjustments in the Evaluation of Events: The "Rosy View," 33 J Exper Soc Psych, 421 (1997); D.A. Amor and S.E. Taylor, When Predictions Fail: The Dilemma of Unrealistic Optimism, in T. Gilovich, D. Griffin, and D. Kahneman, eds, Heuristics and Biases: The Psychology of Intuitive Judgment (Cambridge 2002).

${ }^{25}$ Christine Jolls, Behavioral Economics Analysis of Redistributive Legal Rules, 51 Vand L Rev, 1653 (1998); Cass R. Sunstein, Hazardous Heuristics, 70 U Chi L Rev 751 (2003); Thaler and Sunstein, Nudge (cited in note 22); Tali Sharot, The Optimism Bias: A Tour of the Irrationally Positive Brain (Pantheon 2011).

${ }^{26}$ Peterson, Taming the Sharks (cited in note 5); White, 27 L \& Ineq J at 135 (cited in note 10$)$.

${ }^{27}$ Bar-Gill and Warren, $157 \mathrm{U}$ Pa L Rev at 1 (cited in note 10).

${ }^{28}$ Id at 44.

${ }^{29}$ For their recommendations of something like CFPB, see Elizabeth Warren, Unsafe at Any Rate, 5, Democracy, 8 (2007) online at http:www.democracyjournal.org /5/6528.php?page=all; Elizabeth Warren, Redesigning Regulation: A Case Study from the Consumer Credit to Market (2012).
} 
borrowers finds that most borrowers do not use the product for short periods of time, but rather are indebted for about five months out of each year. ${ }^{30}$ Again, that study works from the premise that the product is designed for immediate repayment, and that use in extended borrowing cycles necessarily is problematic. In their own words, the product's actual use is in "sharp contrast" to its "advertise[ment] as short-term, small-dollar credit intended for emergency or special use. ${ }^{\prime \prime 11}$ Those concerns are even more prominent in the most recent report from the Pew Project, which emphasizes the premise that borrowers "hold unrealistic expectations about payday loans." ${ }^{\prime 32}$

Although the perspective articulated by Bar-Gill, Warren, and Pew has been taken for granted among legal scholars, its analytical shortcomings are apparent. For one thing, as a theoretical matter, it is not at all clear that optimistic behavior reflects poor financial choices. Thus, such empirical evidence as there is suggests that those who are optimistic in fact often (though certainly not always) make better financial choices than those who are not. ${ }^{33}$ Moreover, it is well known that many consumers do a poor job of managing their lifetime consumption and savings choices. The typical "prudent" consumer invests too conservatively, resulting in a substantial shortfall in lifecycle investing; Ayres and Nalebuff vigorously argue that a more "audacious" pattern of behavior would be beneficial. ${ }^{34}$

${ }^{30}$ Pew Project, Payday Lending in America (cited in note 2). Having said that, the overdraft rates reported by the Pew Project, Payday Lending in America: Report 2: How Borrowers Choose and Repay Payday Loans (hereinafter Report 2) 19, 33 (Pew Safe Small-Dollar Loans Research Project Report, 2013), suggest that the Pew sample involves a considerably less creditworthy group of borrowers than the sample analyzed here. This most likely relates to the inclusion in the Pew sample of a large number of online customers (451 storefront customers and 252 internet customers). Pew Project, Report 2 at 55 (cited in note 30). Because those lenders are not readily supervised by state regulators, there is a strong likelihood of more abusive lending and collection practices, and considerable reason to think that the borrowing pool is less creditworthy. Silver-Greenberg, NY Times (Feb 23, 2013) (cited in note 20); Pew Project, Report 2 at 16. The Pew data also warrant caution because they are based on post hoc estimates by borrowers of prior borrowing behavior, rather than direct observation of behavior documented in loan records (the strategy for this project).

${ }^{31}$ Pew Project, Payday Lending in America at 13 (cited in note 2). The suggestion that the lenders are misrepresenting the nature of the product in some way is not unique to the Pew Project. See, for example, White, 27 L \& Ineq J at 159 (cited in note 10) (suggesting that payday loans "are described (falsely) as a short-term credit product, exploiting the consumer's optimism bias").

${ }^{32}$ The Pew Project, Report 2 at 19 (cited in note 30).

${ }^{33}$ Manju Puri and David T. Robinson, Optimism and Economic Choice, 68 J Fin Econ 71 (2007).

${ }^{34} \mathrm{Id}$; Ian Ayres and Barry Nalebuff, Lifecycle Investing: A New, Safe, and Audacious Way to Improve the Performance of Your Retirement Portfolio (Basic 2010). 
Also, as an empirical matter, it seems far too simple to attribute misperception of product use to a vague and general bias toward "optimism." More recent scholars have emphasized the variety of cognitive limitations that might lead to arguably ill-advised borrowing. For example, some borrowing might relate to a misprediction of future self-control (such as a failure to appreciate the likely effects of hyperbolic discounting), a classic example of the optimism bias. ${ }^{35}$ Others recently have emphasized the possibility that scarcity creates a cognitive "load" that might force inattention to the costs of future borrowing. ${ }^{36}$ Still again, some of the borrowing is likely to relate to a misprediction of the income and consumption shocks necessary for repayment to occur. ${ }^{37}$ Thus, absent a research design that can distinguish among those causes, even empirical evidence that borrowers mispredict their use of the product well might reflect any number of problems more or less closely related to excessive optimism.

Against that background, it is distressing that those who seem so sure that all payday loan borrowers are making incorrect choices have failed to observe either the theoretical or empirical ambiguity that plagues their claims. Indeed, legal scholars writing about the role of optimism bias in consumer lending have not for the most part offered empirical evidence; ${ }^{38}$ rather they have imported the findings of the behavioral economists and psychologists into this context, using the possibility of optimism bias to explain increases in consumer borrowing. ${ }^{39}$ Hence, empirical work about the prevalence and significance of optimism among payday loan borrowers has come from other venues.

\footnotetext{
${ }^{35}$ Paige Skiba and Jeremy Tobacman, Payday Loans, Uncertainty and Discounting: Explaining Patterns of Borrowing, Repayment, and Default (Vanderbilt Law and Economics Research Paper No 08-33, Aug 21, 2008), online at http://papers.ssrn.com /sol3/papers.cfm?abstract_id=1319751 (visited July 12, 2013).

${ }^{36}$ Anuj K. Shah, Sendhil Mullainathan, and Eldar Shafir, Some Consequences of Having Too Little, 338 Science 682 (2012).

${ }^{37}$ Ronald J. Mann, After the Great Recession: Regulating Financial Services for Low- and Middle-Income Communities, 69 Wash \& Lee L Rev 729 (2012).

${ }^{38}$ This is of course a commonly noted problem with much of the legal scholarship applying behavioral analysis. Doron Teichman, The Optimism Bias of the Behavioral Analysis of Crime Control, 2011 U Ill L Rev 1697, 1710.

${ }^{39}$ Richard M. Hynes, Overoptimism and Overborrowing, 2004 BYU L Rev 127 (2004); Cass R. Sunstein, Boundedly Rational Borrowing, 73 U Chi L Rev 249 (2006); Nathalie Martin and Ocean Tama y Sweet, Mind Games: Rethinking BAPCPA's Debtor Education Provisions, 31 SIU L J 517 (2006); Adam J. Levitin, Finding Nemo: Rediscovering the Virtues of Negotiability in the Wake of Enron, 2007 Colum Bus L $\operatorname{Rev} 83$ (2007).
} 
An important paper by Bertrand and Morse tests the effectiveness of various disclosure forms in altering perceptions about how the product will work. ${ }^{40}$ Bertrand and Morse also surveyed borrowers about how long they believed payday loans typically remain outstanding; about half the borrowers in their study thought that loans typically remain outstanding beyond the base two-week period. A recent survey by researchers at the Center for Financial Services Innovation asked a sample of borrowers using a variety of alternative financial services, after the fact, if it "took more time than expected to repay the loan." Of the payday loan borrowers, only 32 percent reported that it did take longer than expected. ${ }^{41}$ Similarly, the 2013 report from the Pew Project addresses this question obliquely, finding on the one hand that the overwhelming majority of borrowers report the terms of the transactions as clear but at the same time report that they do not have funds in their monthly budget to repay the loan in one cycle. ${ }^{42}$

Collectively, those studies suggest that payday lending borrowers understand that many borrowers roll over their loans, and that this understanding is, at the most general level, accurate. Neither study, however, sheds any light on the central factual question: how well do individual borrowers understand their own likely future behavior? If optimism in fact is driving these decisions, then borrowers systematically are likely to underestimate the time to repayment. That is the question that motivated this study.

\section{DATA AND METHODS}

\section{A. The Survey}

1. Survey Design. Because the survey instrument was to be administered to borrowers at the point of borrowing, the interest in obtaining a high response rate suggested that it should be concise, limited to one side of a single sheet of paper. Limited by that constraint, the instrument inquires about borrower characteristics, use of the borrowed funds, and borrower expectations about repayment.

${ }^{40}$ Marianne Bertrand and Adair Morse, Information Disclosure, Cognitive Biases, and Payday Borrowing, 66 J Fin 1865 (2011).

${ }^{41}$ Rob Levy and Joshua Sledge, A Complex Portrait: An Examination of SmallDollar Credit Consumers (Center for Financial Services Innovation, Aug 2012), available at http://www.fdic.gov/news/conferences/2012-09-2728/A\%20Complex\%20Portrait .pdf.

${ }^{42}$ Pew Project, Report 2 at 13-17.I (cited in note 30). 
The questions eliciting background data mirror similar questions examined in the existing literature ${ }^{43}$ and help to establish a baseline of the characteristics of the payday loan borrowers in the sample. The instrument collects information about race, age, gender, education, and prior experience with payday lenders.

On the second topic, the instrument offers thirteen specific uses. Borrowers can check as many as apply or add text into a catchall into which borrowers can add written comments; that question tracks precisely the question asked on that topic in Bertrand and Morse ${ }^{44}$ with the addition of an option for education expenses.

The focal point of the survey is assessing the quality of borrower understanding of how the product will be used. Initially, the object was to take the topic of Bertrand and Morse ${ }^{45}$ and test the accuracy of perception, by comparing the borrower's expectation to actual subsequent borrowing and repayment behavior. As it turned out, however, it was far more complicated than expected to modify the Bertrand and Morse survey question for this project.

The Bertrand and Morse survey included the following question: "What's your best guess of how long it takes the average person to pay back in full a $\$ 300$ payday loan? Please answer in weeks." ${ }^{146} \mathrm{In}$ modifying that question for use in this survey, several issues arose, which ultimately led to three separate questions on this topic. The biggest problem relates to the inherent ambiguity of what it means in this context to pay a loan "back in full." As it happens, the law of many states (including the five states in which the survey was given) technically forbids "rollover" loans. ${ }^{47}$ Still, it is possible in most states (including all of the survey states other than Florida) for the lender to conduct same-day transactions in which a new loan is issued on the same day as the loan being paid off. Although the difference between a rollover (collecting a new fee and extending the term of the existing loan) and issuing a new loan shortly after repayment of the old loan might seem technical, it complicates the survey process considerably. For one thing, excluding borrowers who default on the first loan (and there were no such borrowers in this dataset), all borrowers in fact pay the loan back in full at the conclu-

${ }^{43}$ Lawrence and Elliehausen, 26 Contemp Econ Pol at 299 (cited in note 1); Elliehausen, Consumers' Use of Payday Loans (cited in note 1); Michael S. Barr, No Slack: The Financial Lives of Low-Income Americans (Brookings 2012).

${ }^{44}$ Bertrand and Morse, $66 \mathrm{~J}$ Fin at 1870 (cited in note 40).

${ }^{45}$ Id at 1876.

${ }^{46} \mathrm{Id}$.

${ }^{47}$ Cal Fin Code $\S 23037(a)$; Fla Stat $\S 560.404(19)$ (requiring twenty-four-hour cooling-off period between loans); Kan Stat Ann § 16a-2-404(6); La Rev Stat § 9:3578. 6(7) (permitting rollovers only upon partial prepayment); 59 Okla Stat $§ 3109$ (A). 
sion of the first pay period. ${ }^{48}$ Thus, if I had used the Bertrand and Morse question without revision (asking how many weeks it would take for a loan to be paid "back in full"), all borrowers who understood the product and answered truthfully would have responded with an answer indicating the original date of maturity (in this dataset typically something less than fourteen days). Yet if the question is designed to test perceptions about rollovers, such answers would indicate ignorance of the likelihood that many if not most of the borrowers would take out a new loan shortly after repayment of the original loan. ${ }^{49}$ Because of the difficulty of separating the responses that might reflect a literal reading of the question from those that might reflect a colloquial reading of the question, I decided to phrase the question differently.

Trying to ask a question that could be answered with literal accuracy in an informative way, I revised the Bertrand and Morse question and divided it into two separate questions. The first asks about the borrower's anticipation of whether the survey loan will be rolled over: "Do you expect to continue this borrowing after the due date of this loan?" Paired with that question is a follow-up about the extent of likely rollovers, roughly parallel to the Bertrand and Morse estimate: "If so, for how many additional weeks?" To be sure, this question is more complex than the Bertrand and Morse question, and thus poses a risk that subjects will not understand what the question is asking, but ultimately I decided that the virtue of precision justified the more complex phrasing.

A second problem relates to a mismatch between rollovers as the problematic aspect of the product and borrowers being mired in a long-term debt relationship as the ultimate policy concern..$^{50}$ Even if we extend the concept of rollovers to include substantially contemporaneous new borrowings (the subject of the revised question discussed above), we have missed much of what makes the pattern of payday borrowing troubling. In truth, even if a borrower does not roll a loan over, but instead repays the loan out of incoming salary, the borrower has not become free from the cycle of payday borrowing until the borrower goes an entire pay cycle without a new loan. ${ }^{51}$ Thus, the proper topic of inquiry is the length of the borrowing cycle-starting from the initial loan, how much time elapses before the

\footnotetext{
${ }^{48}$ It is apparent, in accordance with applicable local law, that none of the loans in this dataset were rolled over at their original date of maturity.

${ }^{49}$ In the data that I analyze here, for example, 67 percent of the borrowers took out a new loan on the same day as they repaid the initial loan.

${ }^{50}$ Graeber, Debt (cited in note 4); Hyman, Borrow (cited in note 4).

${ }^{51}$ For a detailed discussion of that problem and the weakness of typical state regulatory responses, see Mann and Hawkins, 54 UCLA L Rev at 898 (cited in note 1).
} 
borrower is free from debt in the sense of going an entire pay period without a new loan. ${ }^{52}$ The final question of the survey attempts to gauge expectations about that broader notion of repayment: "We'd like to understand more about your overall financial picture. How long do you think it will be before you have saved enough money to go an entire pay period without borrowing from this lender? If you aren't sure, please give your best estimate."

2. Survey Administration. With the cooperation of a large national payday lender, the survey instrument was administered to borrowers at payday lending stores in a group of five states during the summer of 2012; the goal was for administration to continue at each store until the total number of surveys had reached approximately 1200. The survey was presented to every other eligible borrower. To ensure that the borrower was not in the middle of a borrowing cycle, borrowers who had borrowed during the preceding thirty days were not eligible. ${ }^{53}$ Aside from that exclusion, all borrowers approved for loans were eligible. The reason for presenting the survey only to alternate borrowers was to limit the possibility that potential borrowers would come to the store for the purpose of receiving the modest survey compensation (\$10). In the end, the survey was presented to 1374 borrowers. The response rate was quite high; only forty-eight refused, for a response rate of 96.5 percent. ${ }^{54}$ Table 1 summarizes the distribution of the surveys and store locations among the five states.

\footnotetext{
${ }^{52}$ Fusaro and Cirillo use a similar technique constructing the "spell" of an individual's borrowing. Marc Anthony Fusaro and Patricia J. Cirillo, Do Payday Loans Trap Consumers in a Cycle of Debt (Working Paper, Nov 16, 2011), available at http:// papers.ssrn.com/sol3/papers.cfm?abstract_id=1960776.

${ }^{53}$ Because the focus of the project is on studying the relation between borrowing cycles and borrower expectation, it makes sense to collect a group of borrowers at the beginning of their cycle. To be sure, this is likely to produce a dataset that is more representative of borrowers than it is of loans; because most of the excluded borrowers were those in the middle of a borrowing cycle, a higher share of loans during the survey period were "cycled" loans than extrapolation from this data would suggest. Unfortunately, the data provided to me do not permit me to identify the borrowers excluded for that reason. Accordingly, I cannot identify any differences between the borrowing patterns of customers who were mid-cycle when this survey began and the borrowing patterns of customers who started a new cycle during administration of the survey.

${ }^{54}$ Unfortunately, I did not receive loan numbers for the forty-eight borrowers who refused the survey. As a result, I cannot compare the borrowing characteristics of those borrowers who refused the survey to the borrowing characteristics of those that completed it.
} 
Table 1. Summary of Survey and Store Distribution

\begin{tabular}{lcc}
\hline State & Locations & Surveys \\
\hline California & 24 & 374 \\
Florida & 14 & 447 \\
Kansas & 4 & 86 \\
Louisiana & 11 & 359 \\
Oklahoma & 5 & 60 \\
Total & 58 & 1326 \\
\hline
\end{tabular}

3. Lender Data. Because the purpose of the project was to assess the accuracy of borrower expectations about the product, it was crucial to obtain data about the actual borrowing and repayment practices of the survey subjects. The lender provided access to complete transaction data about all borrowers for a period of twelve months. ${ }^{55}$ Access to this type of data is crucial, because it makes it possible to study the actual patterns of borrowing and repayment at the individual level. For this particular project, it allowed me to examine two aspects of the behavior of payday borrowers that has not previously been studied. First, as discussed above, it allowed me to calculate the actual borrowing cycles for each borrower-I was able to determine for each borrower who answered a survey how long from the date of the contemporaneous loan elapsed before the borrower went an entire pay period without borrowing. ${ }^{56}$ Second, because the survey displays the borrower's expectations about repayment behavior, I was able to compare the borrower's expected repayment behavior to what actually transpired.

${ }^{55}$ Without identifying the lender, I can report that the lender's products are typical of those of large national storefront lenders. Thus, for example, it offers only payday loans as described above, except that it does follow the Community Financial Services Association of America's policy of permitting borrowers to switch to an amortized product after an extended borrowing cycle. It does not appear that any of the borrowers in this dataset took advantage of that opportunity.

${ }^{56}$ To be sure, I can only assess the borrowing cycle from this particular lender, so my data do not account for the possibility that a borrower might start a borrowing cycle with one lender and shift mid-cycle to a different lender. It is difficult to assess the importance of that problem precisely, but given the low transaction costs of continuing with another lender, as compared to switching to a new lender, it seems unlikely to alter the general thrust of the results summarized below. 


\section{V. R E S U L T S}

The most important results of the survey relate to the central questions that motivated the project; three topics warrant detailed discussion. First, most borrowers expected that they would continue borrowing for some time after the initial loan. This undermines the notion (characteristic of much of the legal and policy literature on the subject) that the repeated borrowing that is typical of payday borrowers generally reflects surprise on the part of the borrowers or deception on the part of the lenders. Second, the borrower's predictions about their future repayment behavior, although imperfect, are surprisingly accurate. On the principal question-when would the borrower be free from borrowing for an entire pay period-about 60 percent of the borrowers predicted the final repayment date with reasonable accuracy (within a fourteen-day window, as discussed below). That is to say, most borrowers could predict to within one pay period when they would be free of debt. Moreover, the errors that the borrowers did make were not systematic; thus, because the "optimistic" errors essentially balanced the "pessimistic" errors, the average error in prediction was close to zero. Third, most surprisingly, the demographic characteristics do little to differentiate borrowers in explaining the accuracy of predictions. The strongest and most consistently significant predictor of accuracy are heavy prior use of the product, which relates substantially to poor predictions, and the nature of state regulation, which leads to substantial variation in the quality of predictions (presumably because of differences in the pool of borrowers).

\section{A. Borrower Characteristics}

Before turning to the substantive results, a few words about the characteristics of the borrowing population are warranted. Figure 1 summarizes the distribution by race, gender, age, and educational attainment. As the figure indicates, payday loan borrowers are less likely to be white (less than 25 percent) and more likely to be black (about 50 percent) than the general population, more likely to be female (about 60 percent), likely to be relatively young (the modal group is twenty-five to thirty-four years old), and likely to be relatively well educated (more than half have attended college). ${ }^{57}$ In gen-

${ }^{57}$ There is a substantial group that reports attending college but that has not achieved a BA degree or the equivalent. This is in part due to the young age of that portion of the sample and the concomitant likelihood that their postsecondary education is ongoing. 
Race

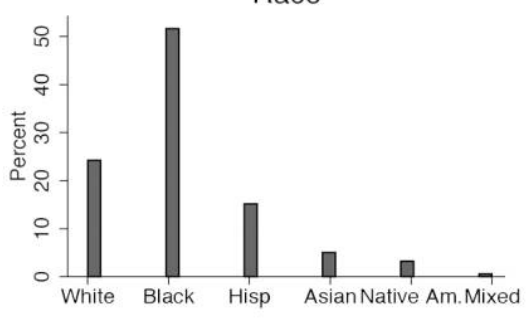

Age

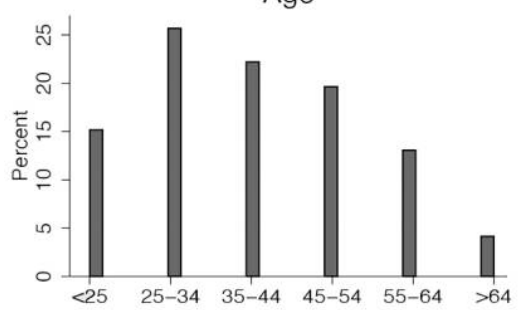

Gender

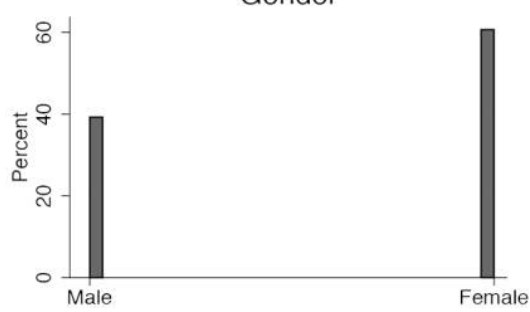

Education

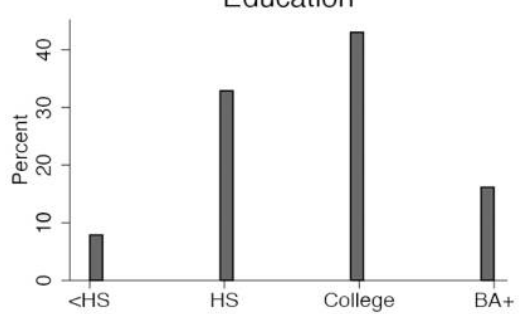

Figure 1. Demographic characteristics of borrowers. Histograms display distribution of demographic characteristics based on survey responses of borrowers. $\mathbf{N}=\mathbf{1 3 1 8}-\mathbf{2 4}$.

eral, those characteristics are consistent with the findings of prior academics that have collected similar information about payday lending customers.

The data about the uses to which the funds are put are also, broadly speaking, similar to prior survey results asking about similar topics. As summarized in Figure 2, in general they show that the dominant use (about two-thirds of all borrowers) is for ordinary recurring expenditures (rent, utilities, groceries, or the like). A much smaller share (about 10 percent) respond to emergencies, and an even smaller share (less than 5 percent) are for leisure expenditures (gifts, dining, and the like). ${ }^{58}$

\section{B. Ex Ante Understanding of Continued Use}

The most straightforward information to come from this survey involves the expectations of payday lending borrowers about the expected length of their borrowing. As summarized above, the survey

${ }^{58}$ About 17 percent report uses in multiple categories. For comparison, see the similar figures in Pew Project, Payday Lending in America at 14 (cited in note 2). 


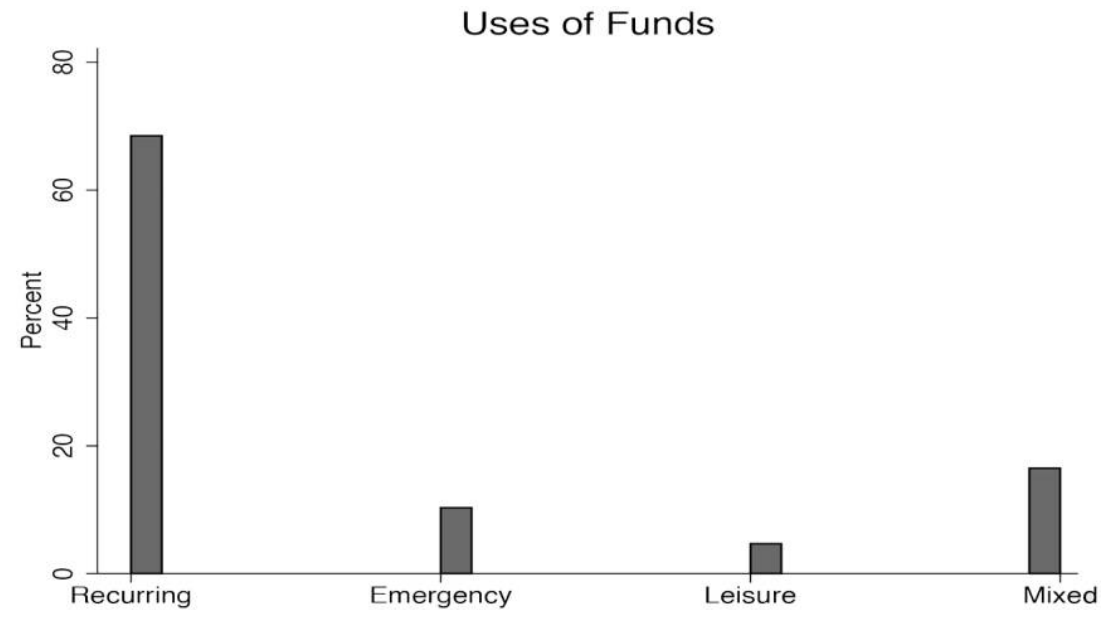

Figure 2. Planned uses of borrowed funds. $\mathrm{N}=1069$. Histograms based only on responsive surveys.

asked a series of closely related questions on that topic. However the question was phrased, a large group of borrowers expected, at the time of their loans, that they would be using the product continuously for a considerable time. So, for example, when asked whether they would "continue" their borrowing after its original due dateessentially whether they anticipated rolling over their loans40 percent $(\mathrm{n}=518)$ thought that they would and another 2 percent $(\mathrm{n}=19)$ wrote in an answer indicating in one way or another that they couldn't be sure ("don't know," "idk," "maybe," "not sure," and so on)..$^{59}$

What is most notable, however, is the variability of expectations about how long the borrowing would continue (the follow-up question to the question whether the borrowing was expected to continue). As the first panel of Figure 3 displays, among the borrowers who offered an estimation as to when they would repay their debt, ${ }^{60}$ a substantial group (more than half) expected that it would

${ }^{59}$ That answer resonates with the concerns emphasized in Mann, 69 Wash \& Lee L Rev at 744-47 (cited in note 37), about the inherent unpredictability of a solution to the financial problems of the desperate.

${ }^{60}$ For a variety of reasons, the number of respondents providing a numerical response to that question was relatively small $(\mathrm{n}=340)$. For one thing, the instrument sought a response only from those that expected to "continue" their borrowing after the initial loan (a little less than half of the respondents). Furthermore, even among the group who did indicate they expected to continue, a substantial group of respondents (about a third) did not answer the question. Finally, as noted above, a number 

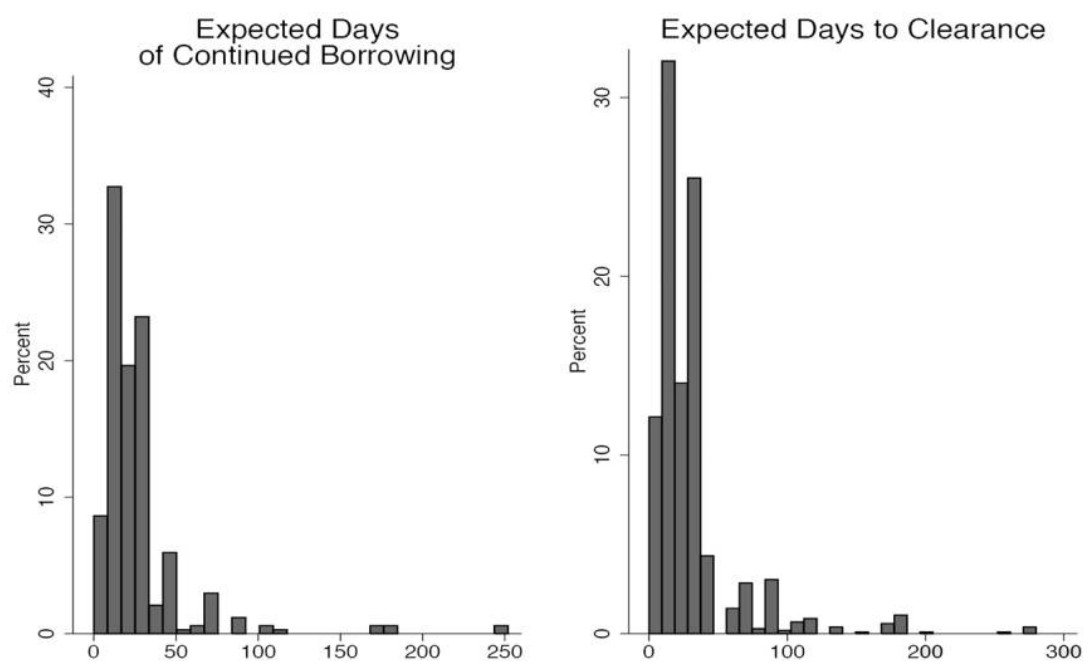

Figure 3. Expected borrowing patterns. First panel $(n=340)$ depicts the number of days the borrower expected the borrowing to continue beyond the original dues date; second panel $(\mathrm{n}=\mathbf{1 0 7 2}$ ) depicts the predicted number of days from loan date to date when borrower expects to be free from debt for an entire pay period. Histograms based on numerical responses only.

take more than twenty days, which is to say that they expected that the borrowing would continue for more than two weeks beyond the due date of the original loan. To put it more clearly, a majority of the respondents to that question contemplated at least three consecutive loans.

Because of the practical ambiguity about what it means to "continue" borrowing in a system in which rolling over a loan is formally unlawful (and thus something that apparently does not happen in any of the stores covered by the surveyl, the broader question about when the borrower expected to be free of debt for an entire pay period seems considerably more instructive about the reality of borrower expectations. The data also suggest some reason to believe that the question made more sense to the borrowers, because they responded to it much more readily: only two-thirds (340/518) of the borrowers who said they would "continue" borrowing responded to the question "how long," but 80 percent of the borrowers $(\mathrm{n}=1072)$ who answered surveys responded with a numeric answer to the question how long it would take for them to be free from debt.

of respondents (about twenty) responded with written text indicating in one way or another that they could not be sure when the borrowing would end. 
The second panel of Figure 3 summarizes the results for that question. The responses suggest a relatively long period of expected borrowing. Thus, looking only to the numerical responses, fully half of all borrowers expected to remain in debt three weeks or more; the mean response was thirty-six days. Because this question was asked of all borrowers (not only those who expected to continue in debt past the period of the original loan), it indicates yet again, using this somewhat different metric, that most of the borrowers expected that they would borrow again after the initial period of debt. What is most striking is the long right tail of the distribution. Fully 10 percent of respondents expected to remain in debt seventy days and 5 percent to remain in debt more than 110 days.

\section{Predicting Freedom from Debt}

The survey responses discussed in the preceding section are not unique. Although the questions are modified somewhat (as discussed above), they are in substance similar to the questions Bertrand and Morse asked about the borrower's understanding of typical product use. What is novel about this data structure, however, is the ability to match those predictions to the actual behavior of the borrowers, which allows a direct test of the extent to which excessive optimism about future behavior relates to borrower use of the product. It is also important that this study examines the cycle of repayment, rather than the narrower question of rollovers. By examining the entire cycle, I get a much more extended (and realistic) understanding of the continuing indebtedness related to a single loan.

There is, to be sure, a glass-half-empty/half-full quality to assessment of the responses. As with the effects of the disclosures that Bertrand and Morse discuss, assessments of borrower psychology depend directly on a baseline intuition about "typical" or "normal" psychology. ${ }^{61}$ So, in this case, an assessment of whether the borrower's predictions are "surprisingly" accurate, inaccurate, optimistic, or pessimistic depends directly on a baseline about how accurate such predictions reasonably could be expected to be.

As it turns out, the difference between the outcomes and predictions is quite varied, with a considerable number of borrowers becoming clear from debt earlier than expected and a considerable number becoming clear from debt later than expected. Overall, the distribution is centered near zero, with long tails extending in both directions; the median error is only three days.

\footnotetext{
${ }^{61}$ Bertrand and Morse, 66 J Fin at 1889-90 (cited in note 40).
} 
Table 2. Accuracy of Predictions of Payday Borrowers

\begin{tabular}{cc}
\hline Window of Predictions (Days) & Percentage On-Time (\%) \\
\hline 7 & 51 \\
14 & 57 \\
21 & 63 \\
\hline
\end{tabular}

Note: $\mathrm{N}=1072$.

Because the purpose of the project is to assess the accuracy of the predictions, it is necessary to determine how best to measure accuracy. Given the rough quality of the predictions (which the survey instrument requests in weeks), it makes little sense in evaluating the predictions to ask whether the debt was repaid on the precise date predicted. Thus, in making a rough judge of the quality of the predictions, it seems sensible to provide for a window on either side of the precise date. Because the lending cycle for these borrowers is the pay period, and because the overwhelming majority of the borrowers appear to have a two-week pay cycle, I ultimately decided to analyze whether the prediction of the date on which the borrower will be clear of debt falls within two weeks of the actual date on which the borrower turns out to become clear of debt. ${ }^{62}$ From that perspective, Table 2 summarizes the central findings of the essay. As the Table indicates, almost 60 percent of respondents managed to become free of debt either before or within two weeks of their predicted date of clearance. To test the robustness of that estimate, I made parallel calculations using seven-day and twenty-one-day windows. Those produced results that bracketed the 57 percent figure for the fourteen-day window: 51 percent for the seven-day window and 63 percent for the twenty-one-day window. To put it conversely, only 43 percent failed to clear themselves from debt within two weeks of their predicted date and less than half were late by more than a week. That is, of course, not an insignificant share, but it does suggest that a strong majority of those using the product have a basic understanding of what will happen when they borrow.

${ }^{62}$ That fourteen-day window is the same window the CFPB used in its white paper examining a similar question. Consumer Financial Protection Bureau, Payday Loans and Deposit Advance Products (White paper, Apr 24, 2013), available at http://files .consumerfinance.gov/f/201304_cfpb_payday-dap-whitepaper.pdf. For purposes of these calculations, this is the number of days from the date of the surveyed advance to the date the borrower repays a loan and has no new borrowings for a period that exceeds fourteen days. For purposes of these calculations, the five borrowers who defaulted on their loans without making payment are treated as late. 


\section{The Role and Experience of Demography}

Although the findings summarized in the previous section suggest that the quality of borrower predictions is reasonably good, it is important to consider the possibility that the quality of predictions relates substantially to race, gender, age, or education. If it were clear, for example, that borrower predictions were systematically less accurate for low-income, elderly, or minority populations, those findings would be considerably less reassuring than they seem at first glance. Figure 4 is a dotplot that summarizes the results of a logistic regression model assessing those relationships. The dependent variable is whether the particular borrower was more than fourteen days late in becoming clear from debt, as compared to the borrower's prediction in the survey instrument. The model includes explanatory variables for the borrower's race, gender, age, education, state of residence, and prior experience with the product. The reference borrower is a white male twenty-five to thirty-four years old residing in California with a college education and some prior experience (reporting one to ten prior transactions) with payday lending. ${ }^{63}$

Because the dataset is relatively small, there may be relatively small effects undetected here, but in general the regressions largely exclude the possibility that demographic characteristics of the borrowers have a substantial effect on the accuracy of borrower predictions. For example, with respect to race, all of the race variables included in the model have positive coefficients, suggesting a greater likelihood of unexpectedly late payment for nonwhite respondents than for white respondents, but none of the coefficients is significant even at the 10 percent level. Similarly, gender appears to be wholly irrelevant. Age produces a substantial result only for the fifty-fiveto sixty-four-year-old group who appear to be about eleven percentage points more likely to have underestimated the repayment period than twenty-five- to thirty-four-year-olds; against a mean of 37 percent, that reflects an increased likelihood of late payment of about 30 percent.

At the same time, geography (presumably at least in part a proxy for differences in the local legal regime) does appear to play a substantial role. Borrowers in Florida are about twelve percentage

\footnotetext{
${ }^{63}$ I investigated the possibility that those effects related to the purpose for which the borrower obtained the initial advance, but found no significant relationships (either for individual purposes or for a variety of aggregated groups of purposes). That well might relate to the relatively small number of borrowers that sought loans for the various purposes included on the survey.
} 


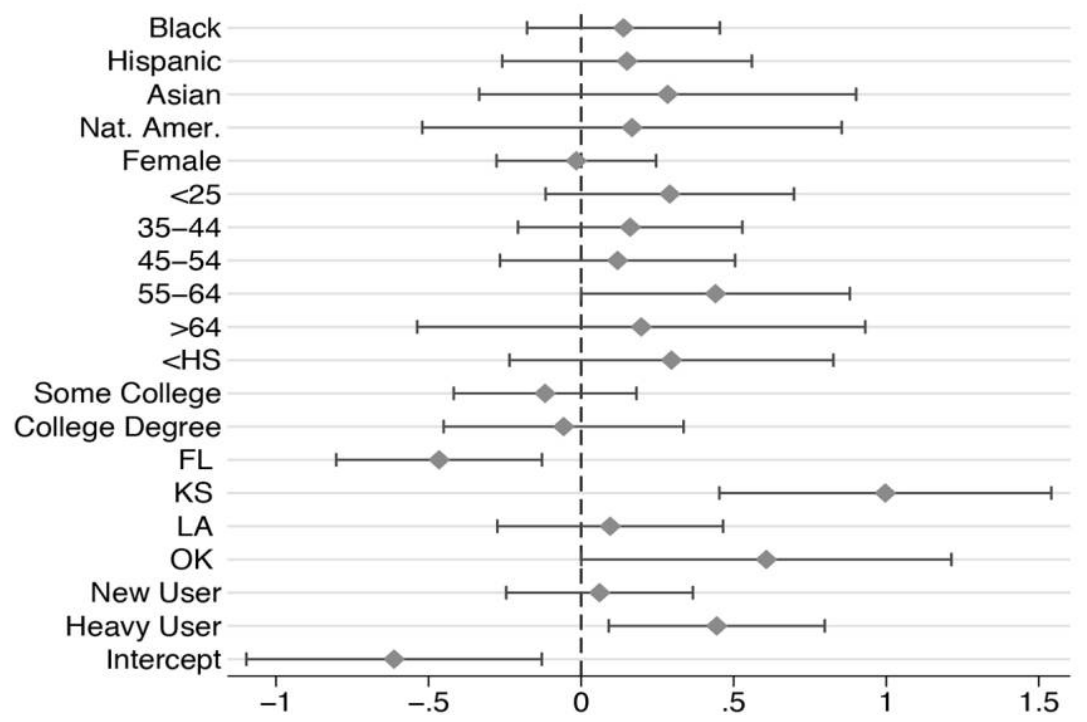

Figure 4. Nomogram predicting results from logistic regression analysis of the effects of geography, demography, and experience, on predicting product usage. $\mathbf{N}=1041$.

points less likely to pay later than expected (as compared to California borrowers), where borrowers in Kansas are about twenty-five percentage points more likely to pay later than expected. The small sample from Oklahoma suggests a likelihood of later-than-expected payment elevated by fifteen percentage points, significant only at the 10 percent level. Although the small group of states in which the survey was administered makes it difficult to interpret those results, it is instructive to look briefly at the differing regulatory regimes in the five survey states to consider potential explanations. Table 3 summarizes salient characteristics of those regimes.

Interestingly, the most constraining regulatory system among the survey states matches up with the outlier on predictive accuracy. Florida's regime is on each of the dimensions summarized in the table the most restrictive: the lowest interest rate, the only defined cooling-off period, and database-verified limitation to one loan. At the same time, as Figure 4 illustrates, Florida borrowers are substantially more accurate than the norm in this data. The most likely explanation is that the Florida borrowers are systemically less risky because the low-interest rate cap and other features of the Florida 
Table 3. Regulatory Regimes in Survey States

\begin{tabular}{|c|c|c|c|}
\hline State & $\begin{array}{l}\text { Highest } \\
\text { Lawful Fee } \\
\text { (per } \$ 100)\end{array}$ & Rollover Constraints & $\begin{array}{c}\text { Multiple Lender/Database } \\
\text { Constraints }\end{array}$ \\
\hline California & $\$ 15$ & $\begin{array}{l}\text { Direct rollovers } \\
\text { prohibited }\end{array}$ & None \\
\hline Florida & $\$ 10$ & $\begin{array}{l}\text { Twenty-four-hour } \\
\text { cooling off period }\end{array}$ & $\begin{array}{l}\text { Twenty-four-hour cooling off } \\
\text { period applies to all lenders; } \\
\text { database verification required }\end{array}$ \\
\hline Kansas & $\$ 15$ & $\begin{array}{l}\text { Direct rollovers } \\
\text { prohibited }\end{array}$ & None \\
\hline Louisiana & $\$ 16.75$ & $\begin{array}{l}\text { Permitted with } \$ 25 \\
\text { partial payment }\end{array}$ & None \\
\hline Oklahoma & $\$ 15$ & $\begin{array}{l}\text { Direct rollovers } \\
\text { prohibited }\end{array}$ & $\begin{array}{l}\text { No more than two loans (from } \\
\text { all lenders) permitted at any } \\
\text { time; database verification } \\
\text { required }\end{array}$ \\
\hline
\end{tabular}

Source: Cal Fin Code §§ 23036(a) \& (c), 23037(a); Fla Stat § 560.404(6), (18) \& (19); Kan Stat Ann $\S 16 a-2-404(1)(c)$ \& (6); La Rev Stat $\S \S 9: 3578.4,6(7) ; 59$ Okla Stat §§ 3108, 3109(A), (B).

statute $^{64}$ limit Florida stores to a more financially stable group of borrowers than the regulatory regimes in the other states. ${ }^{65}$

${ }^{64}$ Among other things, the Florida statute also includes a twenty-four-hour cooling-off period enforced by a database enforcement scheme that is more rigorous than any schemes in the other surveyed states.

${ }^{65}$ It is difficult to tell whether that result is better, or worse, than the results in other states, because it obviously reflects a constraint of credit to the customers to whom it would be profitable to lend under the regulatory regimes of other states. Moreover, it seems quite likely that at least some portion of the relatively less creditworthy borrowers to whom it is unprofitable to extend loans under Florida's regime are resorting to online lenders (whom Florida's regulatory system cannot, practicably, control). The Pew Project does suggest that stronger regulatory regimes do not result in an increased level of online borrowing, but the amount of data on which that conclusion is based makes it difficult to accept at face value. Pew Project, Payday Lending in America at 5, 22 (cited in note 2) Among other things, it is plain that the number of borrowers from any particular state is quite small, which makes it impractical to conduct separate statistical analysis on a state-by-state basis of likely predictors of payday borrowing. Id at 32. It also is relevant that those findings are based on post hoc interviews rather than direct observation of lending activity. Id at 21-23. Similarly, because the analyses involves simple cross-tabulations, which do not control for other state-level characteristics that might influence the demand for payday 
Finally, prior experience with the product has a marked effect, with heavy users (those self-reporting more than ten prior payday loans ${ }^{66}$ being more than eleven percentage points more likely to pay late. This suggests a direction for the relation between product usage and understanding: it is not that understanding of the product comes from prior use. Rather, it is that heavy users of the product tend to be those that understand least what is likely to happen to them. ${ }^{67}$ Related to that point, it appears that those who predict long borrowing periods are those most likely to err substantially in their predictions. ${ }^{68}$ Specifically, both the likelihood of unexpectedly late payment and the proportionate size of the error increase substantially with the length of the borrower's prediction. This does not necessarily mean that heavy users are those that understand the product the least; it may simply indicate that they are the individuals who are in the most serious financial distress, for whom freedom from debt is most difficult to predict. In either event, however, it suggests that prior experience with the product is not an important indicator of improved understanding. ${ }^{69}$

borrowing, their accuracy is quite suspect. In any event, the finding that online borrowing is no higher in aggressive regulatory regimes than in lax regulatory regimes well might relate to the demand for borrowing in the aggressively regulated states (with a relatively low demand for this kind of borrowing relating both to the tolerability of an aggressive regulatory regime and the limited demand for online borrowing).

${ }^{66}$ The survey excludes borrowers who had a loan in the immediately preceding thirty days. The question about prior usage was designed to explore lifetime experience with the product, rather than short-term financial stability. I note that by excluding a group of possibly heavy users that feature of the data collection likely results in a less experienced, but possibly more creditworthy, sample.

${ }^{67}$ A parallel model (not presented here) measuring intensity of use by the number of loans in the previous six months as documented in the lender's records (as opposed to the self-report of previous loans) produced a similar result.

${ }^{68} \mathrm{~A} t$-test suggests that the difference between the likelihood of error for the quartile of borrowers with the shortest predicted borrowing cycle and the likelihood of error for the quartile of borrowers with the highest predicted borrowing cycle is significant at the 1 percent level.

${ }^{69}$ The possibility that a small group of the population does a particularly poor job of making future assessments about financial behavior, and that this might relate to unjustifiable optimism, resonates with the findings of Puri and Robinson, suggesting that individual two standard deviations above the mean (overpredicting their actuarially expected lifetime by more than twenty years) are significantly more likely to make imprudent financial decisions. Puri and Robinson, 68 J Fin Econ at 71 (cited in note 33). 


\section{I M P L I C A T I O N S}

Like the findings reported by Bertrand and Morse ${ }^{70}$ the findings reported here cut in two directions. On the one hand, they suggest that a substantial share of payday lending is rational, in the sense that the borrowers generally understand the outcome of product use at the time they receive an advance of funds. It is not easy, as they note, to develop policy proposals based on data that suggest that large groups of borrowers use the product with an understanding of their future behavior.

Still, the findings are provocative against the backdrop of the understanding of the product that dominates legal and policy-making circles. As suggested above, the basic premise of the regulatory community to date (as reflected in the work of Bar-Gill, Warren, and the Pew Project) is that all uses of the product that lead to a cycle of borrowing are problematic-either because they rest on a prior misunderstanding of the product or, more seriously, because they demonstrate deceit by the lender. That premise, if true, implicitly supports a substantial prohibitory intervention related to the rollover feature of payday loans, at least under the widely held behavioral economics theories of regulation. Although behavioral-based regulatory theorists commonly suggest that regulators should aim strongly toward a "nudge," and should avoid prohibitory regulation, they do recognize the propriety of prohibitory paternalistic intervention that aids an overwhelming majority of borrowers-" "asymmetric" paternalism in the terminology of its most sophisticated advocates. ${ }^{71}$ If it were true, then, that an overwhelming majority (or all) payday lending borrowers who roll over their loans do so because of misperception, then prohibitory intervention would make sense under that theory.

The findings summarized above, however, contradict that argument at its first step. Specifically, they document a set of borrowers, most of whom accurately understand, when they first borrow, how long it will take them to get free of their debt. More generally, those findings are in tension not only with the specific application of the optimism bias idea to payday lending but with the generally quick acceptance, without empirical investigation, of the idea that

\footnotetext{
${ }^{70}$ Bertrand and Morse, $66 \mathrm{~J}$ Fin at 1865 (cited in note 40).

${ }^{71}$ Colin Camerer, et al, Regulation for Conservatives: Behavioral Economics and the Case for Asymmetric Paternalism, 151 U Pa L Rev 1211 (2002); Thaler and Sunstein, Nudge (cited in note 22); Sunstein, 73 U Chi L Rev at 249 (cited in note 39). The strong modern distaste for "hard" paternalism is not unique to American regulators, but appeals to the British as well. Financial Conduct Authority, Applying Behavioral Economics at the Financial Conduct Authority 47-50 (2013).
} 
substantially all of the financial behavior of the less sophisticated is plagued by such misperceptions. That finding has two direct implications for regulatory design. First, it strongly undermines the likely efficacy of even a relatively forceful "nudge," the kind of "sticky default" that Michael Barr and Sendhil Mullainathan have advocated for mortgage regulation. ${ }^{72}$

Second, it starkly undermines the conventional case for modern prohibitory behavioral regulation. As summarized above, the "golden rule" of regulation sought by the leading school of behaviorally influenced policymakers rests on the empirical premise that substantially all of the affected population would make the choice sought by the regulator (in this case, not to roll over the loan, or not to enter into it if roll over seemed likely). The empirical assumptions of Bar-Gill, Warren and others play directly into that regulatory framework. But without those empirical assumptions, the case for a "golden" exercise of asymmetric paternalism is simply not available.

To be sure, at first glance there might seem some cause of concern for the 40 percent of borrowers who do not accurately foresee their use of the product. The natural question, however, is what share of borrowers could predict their future use of any modern financial product. Because scholars have not conducted similar surveys for other competing financial products, it is difficult to compare the approximately 60 percent share of payday lending borrowers who have a reasonably accurate perception of how they will use the product with the shares that could make similarly accurate predictions about other financial products. Still, many products might fare much worse on that metric. Is it fair to expect, for example, that 60 percent of those who borrow on a credit card could predict within two weeks the date on which they would finally repay all outstanding debt on the card $?^{73}$ It would make little sense for regulatory intervention

\footnotetext{
${ }^{72}$ Mullainathan is now the Assistant Director for Research at the CFPB, and it is reasonable to think his views influenced the CFPB's recently promulgated comprehensive reform of mortgage disclosure regulation. See Bureau of Consumer Financial Protection, High-Cost Mortgage and Homeownership Counseling Amendments to the Truth in Lending Act (Regulation Z) and Homeownership Counseling Amendments to the Real Estate Settlement Procedures Act (Regulation X); Final Rule, 78 Fed Reg 6856 (2013). Michael S Barr, Sendhil Mullainathan, and Eldar Shafir, The Case for Behaviorally Informed Regulation, in David Moss and John Cisternino, eds, New Perspectives on Regulation 25, 27 (Tobin Project 2009), available at http://www .tobinproject.org/sites/tobinproject.org/files/assets/New_Perspectives_Full_Text.pdf.

${ }^{73}$ Oren Bar-Gill, Seduction by Contract: Law, Economics, and Psychology in Consumer Markets 89-90 (Oxford 2012).
} 
based on misperception to shift borrowers to other products that are plagued by higher rates of misperception than payday loans.

The closest recent information on this subject comes from Levy and Sledge, who ask users of a variety of alternative financial services whether it took them longer than expected to repay the loan. ${ }^{74}$ Their results suggest that payday loans are not an outlier with respect to predictability of repayment: they found that 32 percent of payday lending borrowers reported taking longer than expected to repay their loans, as compared to 32 percent of auto title loans, 29 percent of pawn loan borrowers, and 20 percent of bank deposit advance borrowers.

The obvious implications, then, are that the strongest case for direct regulation of payday rollovers is a direct exercise of paternalism, based not on the idea that informed customers would choose not to borrow when roll over seems likely, but rather on the regulatory conclusion that borrowers should not be allowed to have those loans even if they understand their consequences. Although this regulatory approach often is appealing to policy-making think tanks, ${ }^{75}$ it is much less likely to find favor with the more mainstream academic regulatory analysts. ${ }^{76}$ Thus, for example, Cass Sunstein has directly disavowed the propriety of this kind of regulation. ${ }^{77}$ In that context, at least, with such a limited empirical understanding of either the factors that lead to the continuing high demand for high-cost credit or the factors that make other credit alternatives seem so much more expensive to the customers, the quick choice of prohibitory regulation seems more like a palliative cop-out than a bold reform. In truth, what is needed is a better understanding of the financial problems of the increasing number of low- and middle-income households in our economy, coupled with a frank assessment of the problems with the

\footnotetext{
${ }^{74}$ Because Levy and Sledge inquired about product use retrospectively—asking borrowers about their past use-it is possible that their results overstate the accuracy of borrowing expectations: the likelihood that a "hindsight bias" would lead borrowers after the fact to remember their performance as having been better than it actually was. Still, because they used a similar methodology for several products, their results provide a useful benchmark for comparing the role of misperception for different products. Levy and Sledge, A Complex Portrait (cited in note 41).

${ }^{75}$ The 2013 Pew Report takes this tack directly. Pew Project, Report 2 at 5 cited in note 30). Still, their survey results resonate strongly with the findings discussed above-they report that 88 percent of storefront customers say the terms of lending are clear. Id at 16.

${ }^{76}$ That is not to say there is no serious academic support for paternalistic regulatory intervention. For one serious effort to defend that form of regulation. See Eyal Zamir, The Efficiency of Paternalism, 84 Va L Rev 229 (1998).

${ }_{77}$ Sunstein, 73 U Chi L Rev at 249 (cited in note 39); Sunstein, 78 U Chi L Rev at 1349 (cited in note 21).
} 
social safety net that lead to the desperate demand for short-term credit that the Pew Project documents. ${ }^{78}$

\section{CON CLUSION}

Payday loans are a fascinating topics for the regulatory analyst. Reviled for abusiveness by middle- and upper-class academics, the product remains intensely attractive to those for whom it is designed. Thus, looking forward from the immediate regulatory possibilities discussed above, the findings suggest a wide variety of possibilities for further research. The most obvious possibility would be to probe the rationality of the borrowing decision in the first place. As discussed above, much literature has assumed that the decision to borrow expecting rollovers cannot be rational. If the data presented here suggest that most borrowers are making that choice consciously, it suggests the value of further inquiry into the longer-run status of balance-sheet deterioration of payday lending borrowers. Here, the suggestion of Agarwal Skiba, and Tobacman that payday loan borrowing often reflects a long-term loss of liquidity from other sources, such as credit cards, well might show the way to a broader understanding of the relevant balance-sheet problems. ${ }^{79}$

Extending the work in a different direction, broader surveys of payday lending borrowers could explore the geographic variation identified above, with a view to identifying any relation between the share of misperceiving borrowers and the rigor (or laxity) of state regulation. ${ }^{80}$ Extension of the survey to online lenders (who have a much more aggressive business model) could explore the likelihood that the users of online loans are more likely to suffer from misperception. And more ambitiously, similar surveys of users of other financial products could document the relative accuracy of borrower understandings of those products. To the extent those products use

\footnotetext{
${ }^{78}$ Working in that vein, Morgan suggest that bans on payday loans are associated with an increase in bounced checks and overdraft fees. Morgan, Strain, and Seblani, 44 J Money Credit Bank at 519 (cited in note 3).

${ }^{79}$ Sumit Agarwal, Paige Marta Skiba, and Jeremy Tobacman, Payday Loans and Credit Cards: New Liquidity and Credit Scoring Puzzles? 99 Am Econ Rev 412 (2009).

${ }^{80}$ Researchers might examine, for example, whether any shift in borrowing patterns occurred after the adoption of more modern disclosure requirements, such as the recent Texas statute requiring preloan disclosure of typical repayment patterns (Hutchings and Nance, 66 Consumer Fin L Q Rep 76 (cited in note 12)), patterned on the disclosures tested by Bertrand and Morse, 66 J Fin 1865 (cited in note 40). Although I generally am skeptical of the utility of disclosures, data on their effectiveness in this context is admittedly limited.
} 
different regulatory and disclosure regimes the comparative results might foster an understanding of the value (or futility ${ }^{81}$ of those regimes. Similarly, to the extent that behavioral regulatory interventions more broadly are premised on misperception, such studies would help to focus interventions on the products where misperceptions are most pervasive.

${ }^{81}$ See Omri Ben-Shahar and Carl E. Schneider, The Failure of Mandated Disclosure, 159 U Pa L Rev 647 (2010). 